\title{
Effect of progesterone on LH-releasing activity of the hypothalamus in non-laying hens primed with oestradiol
}

\author{
M. Kawashima, M. Kamiyoshi, K. Tanaka, M. Hattori* and \\ K. Wakabayashi*
}

Department of Poultry and Animal Sciences, Gifu University, Kakamigahara, Gifu, and

*Institute of Endocrinology, Gunma University, Maebashi, Japan

\begin{abstract}
Summary. LH-releasing activity of the hypothalamus in non-laying hens following the injection of progesterone was increased in hens that had been treated with oestradiol $4 \mathrm{~h}$ earlier. Short-term priming with oestradiol may be effective in increasing the responsiveness of the hen hypothalamus to progesterone.
\end{abstract}

\section{Introduction}

In laying hens (Gallus domesticus), the concentrations of plasma progesterone and LH change during the ovulatory cycle and each shows a peak some several hours before ovulation (Laguë, van Tienhoven \& Cunningham, 1975; Shodono, Nakamura, Tanabe \& Wakabayashi, 1975). Since progesterone is known to stimulate the release of LH from the pituitary (Wilson \& Sharp, 1975a, b; Etches \& Cunningham, 1976) by acting on the central nervous system including the hypothalamus (Fraser \& Sharp, 1978), a positive feedback action of progesterone for the release of LH during the ovulatory cycle has been proposed (Sharp, 1980). Although the injection of progesterone causes an increase in the hypothalamic gonadotrophin-releasing activity in the laying hen, the effect was not apparent in the non-laying hen (Tanaka, Kamiyoshi \& Sakaida, 1974). The cytoplasmic progesterone receptor concentration in the hypothalamus is less in non-laying than in laying hens (Kawashima, Kamiyoshi \& Tanaka, 1979a). A single intramuscular injection of oestradiol into non-laying hens causes an increase in the cytoplasmic progesterone receptor concentration in the hypothalamus within $4 \mathrm{~h}$ of injection (Kawashima et al., 1979b). It is assumed therefore that the effect of progesterone on the hypothalamus may be enhanced by the single injection of oestradiol $4 \mathrm{~h}$ before the injection of progesterone. The present experiments were performed to examine this assumption.

\section{Materials and Methods}

\section{Birds and treatments}

The White Leghorn hens used ( 20 months of age; $1.9-2.2 \mathrm{~kg}$ body wt) had not laid an egg for 1 week after a 3-day deprivation of food and water. The 80 birds were divided into 4 groups, and each received an injection of oestradiol or olive oil and a subsequent injection, $4 \mathrm{~h}$ later, of progesterone or oil. The steroids were dissolved in olive oil, and the injections were made intramuscularly at a dose of $0.5 \mathrm{mg} / \mathrm{bird}$. The volume of injections was $0.5 \mathrm{ml}$. The birds were killed 1 or $4 \mathrm{~h}$ after the second injection, and the hypothalamic tissue was obtained by dissecting the brain just posteriorly to the optic chiasma, anteriorly to the oculomotor nerve, to $1 \mathrm{~mm}$ each 
side of the midline, and to a depth of approximately $1 \mathrm{~mm}(20-28 \mathrm{mg} / \mathrm{hen})$. The part of the hypothalamus obtained was the same as in our earlier investigations on progesterone receptors (see Kawashima et al., 1980).

\section{Preparation of hypothalamic extracts}

The hypothalamic tissues were pooled and homogenized in 10 volumes of ice-cold $0 \cdot 1$ $\mathrm{N}-\mathrm{HCl}$. The homogenates were centrifuged $\left(1000 \mathrm{~g}, 15 \mathrm{~min}, 4^{\circ} \mathrm{C}\right)$, and the supernatant fluid was neutralized with $1 \mathrm{~N}-\mathrm{NaOH}$ and again centrifuged. The supernatant fluid was adjusted to $\mathrm{pH} 7 \cdot 3$ with $0.1 \mathrm{~N}-\mathrm{NaOH}$, and filtered $(0.5 \mu \mathrm{m}$ millipore filter). The filtrates were diluted with Eagle's minimal essential medium (MEM) containing Romanoff's avian Ringer salt (RRA) (Romanoff, 1943), and used immediately for LH-RH assay.

\section{LH-RH assay}

LH-releasing activity of the hypothalamic extracts was assayed on isolated hen pituitary cells in vitro by a method similar to that reported by Bicknell \& Follett (1975) and Bonney \& Cunningham (1977) with modifications. Anterior pituitary lobes were excised from laying hens. In each assay, 40 hens were used as donors of the pituitary. Trypsinization was carried out with $0.25 \%(\mathrm{w} / \mathrm{v})$ trypsin in $\mathrm{Ca}^{2+}$ - and $\mathrm{Mg}^{2+}$-free $\mathrm{RRA}$ solution to which bovine serum albumin (BSA; Fraction V, Armour, Illinois, U.S.A.) was added. The addition of BSA has been reported to be helpful in maintaining the function of the cellular membrane of rat pituitary cells (Hymer $e t$ al., 1973). The pituitary cells were suspended in Eagle's MEM-RRA at a concentration of $1 \times$ $10^{6} / \mathrm{ml}$, and $0.5 \mathrm{ml}$ of the suspension was placed in tubes. The hypothalamic extracts $(0.5 \mathrm{ml})$ or standard LH-RH solution $(0.5 \mathrm{ml})$ was added to the tubes, and also to another series of tubes into which $0.5 \mathrm{ml}$ Eagle's MEM-RRA not containing the pituitary cells was dispensed. Four tubes containing the pituitary cells and 3 tubes not containing the pituitary cells were used for each dose of the hypothalamic extracts and of the standard LH-RH solution, and 4 tubes containing the pituitary cell suspension $(0.5 \mathrm{ml})$ and Eagle's MEM-RRA $(0.5 \mathrm{ml})$ served as controls. All tubes were incubated for $2 \mathrm{~h}$ at $41^{\circ} \mathrm{C}$ under an air atmosphere in a shaking (120 r.p.m.) water bath. After the incubation, the tubes were immediately cooled in an ice-bath, and gently centrifuged $\left(180 \mathrm{~g}, 5 \mathrm{~min}, 4^{\circ} \mathrm{C}\right)$. The supernatant fluid was decanted and stored at $-20^{\circ} \mathrm{C}$. The amount of $\mathrm{LH}$ was measured by a radioimmunoassay for avian LH (Hattori \& Wakabayashi, 1979). A highly purified chicken LH (Fraction IRC-2, Gunma) was used as a standard. The amount of LH measured in the tubes containing the pituitary cells minus the amount of $\mathrm{LH}$ in the tubes not containing the pituitary cells is equivalent to the amount of $\mathrm{LH}$ released both spontaneously and by the test material. The increase in the amount of $\mathrm{LH}$ released by the test material was obtained by further subtracting the amount of $\mathrm{LH}$ in the control tubes. The LH-RH concentration of the hypothalamic extracts was determined by a 4-point design $(2+2)$, and expressed as $\mathrm{ng}$ equivalents of NIH-LH-RH/FSH-RH (NICHO-72-2722 CPR) per mg hypothalamic tissue. Statistical significance of the difference of the LH-RH concentration between groups was analysed by $t$ test (Snedecor, 1956) on the values of distance $(M)$ from the standard line in the 4-point assays (Finney, 1964).

In preliminary experiments, (1) viability of the pituitary cells during the incubation, (2) time course of $\mathrm{LH}$ release by the hypothalamic extracts and by the standard LH-RH during the incubation, (3) dose-response relationship for the hypothalamic extracts and the standard LH-RH, and (4) specificity of the response for the hypothalamic extracts among the extracts of various tissues were examined. It was found that (1) the viability was $99 \%$ or more up to $16 \mathrm{~h}$ of incubation, (2) the increase in the amount of $\mathrm{LH}$ released showed a maximum (hypothalamic extracts) or a plateau (standard LH-RH) at $2 \mathrm{~h}$ of incubation, (3) a linear relationship between the $\log$ dose and the amount of $\mathrm{LH}$ released occurred for the hypothalamic extracts $(2 \cdot 5-10 \mathrm{mg}$ 
equiv.) and the standard LH-RH (80-320 ng), and the lines were parallel, and (4) there was no increase in LH release when extracts from cerebellum (5, 10 and $20 \mathrm{mg}$ ), posterior lobe of pituitary $(0.5,1$ and $2 \mathrm{mg}$ ) and superficial pectoral muscle $(5,10$ and $20 \mathrm{mg})$ were incubated for 2 h.

\section{Results}

As shown in Table 1, the concentration of LH-RH in the hypothalamus of non-laying hens was greater in the hens receiving the injection of oestradiol before the injection of progesterone (Group 1) than in the hens in Groups 2, 3 and 4 at $1 \mathrm{~h}$ and Groups 3 and 4 at $4 \mathrm{~h}$. Although Group- 2 hens showed a greater LH-RH concentration at $1 \mathrm{~h}$, there was no appreciable difference between values for hens in Groups 3 and 4.

Table 1. LH-RH concentration (and 95\% fiducial limits) in the hypothalamus 1 and $4 \mathrm{~h}$ after the injection of progesterone or oil into non-laying hens (20/group) pretreated with oestradiol or oil

\begin{tabular}{|c|c|c|c|c|}
\hline \multirow[b]{2}{*}{ Group } & & & \multicolumn{2}{|c|}{ LH-RH concentration $(\mathrm{ng} / \mathrm{mg}) \dagger$} \\
\hline & \multicolumn{2}{|c|}{ Treatment* } & $1 \mathrm{~h}$ & $4 \mathrm{~h}$ \\
\hline 1 & Oestradiol & Progesterone & $41 \cdot 21(27 \cdot 16-62 \cdot 37)$ & c32.43(25.24-41.69) \\
\hline 2 & & Progesterone & ${ }^{b} 24.60(19.32-31.62)$ & $24.27(19.54-30.06)$ \\
\hline 3 & Oestradiol & Oil & $15 \cdot 89(11.43-22 \cdot 13)$ & $18.29(14.62-24.49)$ \\
\hline 4 & Oil & Oil & $16.79(13.74-20.51)$ & $19.59(15.78-24.32)$ \\
\hline
\end{tabular}

* Intramuscular injections $4 \mathrm{~h}$ apart.

† Equivalents of NIH-LH-RH/FSH-RH determined by 4-point assays. The doses used were $S$ and $10 \mathrm{mg}$ equiv. of the extracts, and 160 and $320 \mathrm{ng}$ standard LH-RH. The indices of precision $(\lambda)$ of assay ranged from 0.074 to 0.100 .

Bignificantly different from value for Group $2(P<0.05)$, Group $3(P<0.01)$ and Group $4(P<0.001)$.

b Significantly different from value for Group $4(P<0.02)$.

' Significantly different from value for Group $3(P<0.001)$ and Group $4(P<0.001)$.

\section{Discussion}

The results indicate that, in respect of the LH-releasing activity of the hypothalamus of non-laying hens, a single intramuscular injection of oestradiol induces a greater response to progesterone given $4 \mathrm{~h} \mathrm{after}$ the injection of oestradiol. Since the cytoplasmic progesterone receptor concentration in the hypothalamus of the non-laying hen increases within $4 \mathrm{~h}$ of the injection of oestradiol (Kawashima et al., 1979b), the greater response to progesterone may be due to the increase in the amount of receptors in the tissue. Although priming the hypothalamus by repeated injections of oestradiol benzoate on alternate days for 7 days before the induction of LH release by progesterone has been reported for ovariectomized pullets (Wilson \& Sharp, 1976), the present data suggest that only one priming injection of oestrogen is effective for the induction of LH release in non-laying hens.

The data also indicate that the injection of progesterone alone causes the increase in the hypothalamic LH-releasing activity in non-laying hens (Group 1 versus Group 3, and Group 2 versus Group 4). This is not in agreement with previous results which did not show any appreciable increase in the gonadotrophin-releasing activity of the hypothalamus in non-laying moulting hens (Tanaka et al., 1974). The discrepancy may be due to a difference in the method of assay and/or the birds used, because in the previous study the assay method was less sensitive 
(a bioassay using ${ }^{32} \mathrm{P}$ uptake by chick testes which measures LH and FSH activities) and the hens had not laid for a longer period. Nevertheless, the results in the present study support the concept that oestrogen primes the hypothalamus of the hen for the release of LH-releasing hormone and that progesterone exerts its action on the hypothalamus as an inducing agent for the release of $\mathrm{LH}$ for ovulation.

We thank the National Institute of Arthritis, Metabolism and Digestive Diseases, Bethesda, Maryland, U.S.A. for the supply of LH-RH/FSH-RH. This study was supported by Grants-in-Aid from the Ministry of Education, Science and Culture (436025), Japan.

\section{References}

Bicknell, R.J. \& Follett, B.K. (1975) A quantitative assay for luteinizing hormone releasing hormone (LHRH) using dispersed pituitary cells. Gen. comp. Endocr. 26, 141-152.

Bonney, R.C. \& Cunningham, F.J. (1977) A role for cyclic AMP as a mediator of the action of LH-RH on chicken anterior pituitary cells. Mol. cell. Endocr. 7, 233-244.

Etches, P.J. \& Cunningham, FJ. (1976) The interrelationship between progesterone and luteinizing hormone during the ovulation cycle of the hen (Gallus domesticus). J. Endocr. 71, 51-58.

Finney, D.J. (1964) Statistical Method in Biological Assay, 2nd edn. Charles Griffin, London.

Fraser, H.M. \& Sharp, P.J. (1978) Prevention of positive feedback in the hen (Gallus domesticus) by antibodies to luteinizing hormone releasing hormone. $J$. Endocr. 76, 181-182.

Hattori, M. \& Wakabayashi, K. (1979) Isoelectric focusing and gel filtration studies on the heterogeneity of avian pituitary luteinizing hormone. Gen. comp. Endocr. 39, 215-221.

Hymer, W.C., Evans, W.H., Kraicer, J., Mastro, A., Davis, J. \& Griswold, E. (1973) Enrichment of cell types from the rat adenohypophysis sedimentation at unit gravity. Endocrinology 92, 275-287.

Kawashima, M., Kamiyoshi, M. \& Tanaka, K. (1979a) Cytoplasmic progesterone receptor concentrations in the hen hypothalamus and pituitary: difference between laying and nonlaying hens and changes during the ovulatory cycle. Biol. Reprod. 20, 581585.

Kawashima, M., Kamiyoshi, M. \& Tanaka, K. (1979b) Effect of progesterone, estradiol and testosterone on cytoplasmic progesterone receptor concentrations in the hen hypothalamus and pituitary. Biol. Reprod. 21, 639-646.

Kawashima, M., Kamiyoshi, M. \& Tanaka, K. (1980) Relationship between the changes in cytoplasmic progesterone receptor concentration and in nuclear progesterone binding sites in the hen hypothalamus and pituitary during the ovulatory cycle. Endocr. Japon. 27, 667-670.

Laguë, P.C., van Tienhoven, A. \& Cunningham, F.J. (1975) Concentrations of estrogens, progesterone and LH during the ovulatory cycle of the laying chicken (Gallus domesticus). Biol. Reprod. 12 590-598.

Romanoff, A.L. (1943) Differentiation in respiratory activity of isolated embryonic tissues. $J$. exp. Zool. 93, $1-26$.

Sharp, P.J. (1980) Female reproduction. In Avian Endocrinology, pp. 435-454. Eds A. Epple \& M. H. Stetson. Academic Press, New York.

Shodono, M., Nakamura, T., Tanabe, Y. \& Wakabayashi, K. (1975) Simultaneous determinations of oestradiol- $17 \beta$, progesterone and luteinizing hormone in the plasma during the ovulatory cycle of the hen. Acta endocr., Copenh. 78, 565-573.

Snedecor, G.W. (1956) Statistical Methods, 5th edn. Iowa State University Press, Ames.

Tanaka, K., Kamiyoshi, M. \& Sakaida, M. (1974) Effects of progesterone on the hypothalamic gonadotropin-releasing activity and on the pituitary gonadotropic activity in hens and cocks. Poult. Sci. 53, 1772-1776.

Wilson, S.C. \& Sharp, P.J. (1975a) Changes in plasma concentrations of luteinizing hormone after injection of progesterone at various times during the ovulatory cycle of the domestic hen (Gallus domesticus). $J$. Endocr. 67, 59-70.

Wilson, S.C. \& Sharp, P.J. (1975b) Effects of progesterone and synthetic luteinizing hormone releasing hormone on the release of luteinizing hormone during sexual maturation in the hen (Gallus domesticus). $J$. Endocr. 67, 359-369.

Wilson, S.C. \& Sharp, P.J. (1976) Induction of luteinizing hormone release by gonadal steroids in the ovariectomized domestic hen. J. Endocr. 71, 87-98.

Received 16 April 1981 